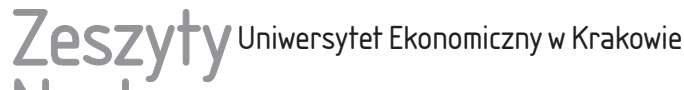 Naukowe
}

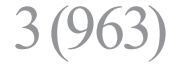

ISSN 1898-6447

Zesz. Nauk. UEK, 2017; 3(963): 69-86 DOI: 10.15678/ZNUEK.2017.0963.0305

Anna Karwinska

\section{Przestrzenie pamięci w miastach o trudnej historii. Konflikty wokół narracji miejskich*}

\section{Streszczenie}

Artykuł poświęcony jest problematyce miast, w których pojawiają się kontrowersje wokół przestrzeni pamięci, powstających jako efekt rozmaitych procesów historycznych. Różne grupy mieszkańców i użytkowników wytwarzają społeczne przestrzenie znaczące, wypracowują najbardziej odpowiednie sposoby wykorzystywania miejsc i wydarzeń historycznych do budowania wizji miasta i swojej w nim obecności. Niektóre obszary miasta mogą mieć trudną przeszłość, w których przeplata się ze sobą dziedzictwo chciane i niechciane. „Pamięć”, także ta, zawarta w przestrzeni miejskiej, może być traktowana jako swoiste narzędzie do określania siebie w relacji do innych, a także do tworzenia poczucia sensu własnych działań, wyborów, których się dokonuje, kryteriów ocen. Posługując się różnymi przykładami miast o trudnej historii, w artykule przedstawiono tezę o kontrowersyjnym charakterze tworzonych przez różne zbiorowości przestrzeni pamięci.

Słowa kluczowe: przestrzenie pamięci, miasto o trudnej historii, palimpsest, Gliwice.

Anna Karwińska, Uniwersytet Ekonomiczny w Krakowie, Wydział Gospodarki i Administracji Publicznej, Katedra Socjologii, ul. Rakowicka 27, 31-510 Kraków, e-mail: karwinsa@uek. krakow.pl

* Artykuł powstał w ramach badań statutowych Katedry Socjologii finansowanych ze środków własnych przez Uniwersytet Ekonomiczny w Krakowie. 


\section{Wprowadzenie}

Miasto jest bardzo złożonym środowiskiem społeczno-przestrzennym. Od samego początku powstania tego nowego typu osadnictwa było miejscem spotykania się kultur, różnych sposobów myślenia i działania, różnych tradycji i doświadczeń. Ukonstytuowanie się miasta było odpowiedzią na nowe potrzeby i nowe aspiracje, w tym także na potrzeby powstawania specyficznej ,przestrzeni możliwości”. „Niekompletność” złożonego systemu, jakim jest miasto, daje możliwości twórczych procesów w różnych dziedzinach (zob. [Sassen 2014, s. 1]). Miasto to także konglomerat rozmaitych grup, kręgów, które z różnych powodów" bywają wykluczane, niewidzialne, pozbawiane szans wyrażania siebie i swoich wartości w przestrzeniach publicznych, zwłaszcza jeśli szerszy kontekst społeczny ma cechy autorytarne. Jednak zazwyczaj każda (lub niemal każda) grupa w owej złożonej zbiorowości miejskiej wytwarza społeczne przestrzenie znaczące, wypracowuje najbardziej odpowiednie sposoby wykorzystywania miejsc i wydarzeń historycznych do budowania wizji miasta i swojej w nim obecności. Niektóre obszary miasta mogą mieć „trudną” przeszłość, w których przeplatają się ze sobą dziedzictwo chciane i niechciane, w których różne grupy tworzą swoje własne wersje miasta (dzielnicy czy mniejszego obszaru), wybierając z bogatego, złożonego przekazu te wątki, te miejsca czy te wydarzenia, które są im najbliższe. Takie sytuacje często stają się podstawą konfliktów, zarówno w przestrzeniach publicznych, jak i w praktykach społecznych.

W rozważaniach nad życiem społecznym „pamięć” może być traktowana jako swoiste narzędzie określania siebie w relacji do innych, a także tworzenia poczucia sensu własnych działań, wyborów, których się dokonuje, kryteriów ocen. Jak wskazuje M. Baucharowicz, pamięć pozwala na zmniejszanie skutków wyroków historii, zwłaszcza utraty tego co najważniejsze, najbardziej kochane [Baucharowicz 2012, s. 32-33]. Potrzebne są przedmioty, miejsca, symbole, które pozwalają na przywołanie przeszłości, zanurzenie się w inny czas, odtworzenie utraconego miejsca.

$\mathrm{W}$ artykule postawiono tezę, że tak tworzone przestrzenie pamięci, konstrukty indywidualne i zbiorowe mają często charakter kontrowersyjny. Odpowiadają na odmienne potrzeby, są budowane z pewnych fragmentów materialnych i niematerialnych, dobieranych z nieoczywistych (z punktu widzenia współmieszkańców czy współużytkowników miasta) powodów. Także konstruowany na ich podstawie przekaz (komunikat) niekoniecznie dla wszystkich jest tak samo zrozumiały, czasem jest oceniany jako „fałszywy” przez pewne środowiska, a przez inne jako „prawdziwy”. Trudno jednoznacznie ocenić zarówno kształt i zawartość przestrzeni pamięci, jak i związane z nimi narracje, zawsze muszą być rozważane 
w kontekście społeczno-kulturowym. Prowadzone rozważania zostały uzupełnione o przykład Gliwic - miasta o trudnej historii.

\section{Przestrzenie pamięci i ich społeczne funkcje}

Przestrzeń miejska stanowi ramy materialne dla intensywnego życia publicznego. Jest ona nieustannie, zbiorowo, wytwarzana przez uczestników rozmaitych procesów zachodzących w tym obszarze i w związku z nim. Dzieje się tak poprzez praktyki społeczne mieszkańców miast, tworzenie określonych sposobów życia, działania dzięki poczuciu wartości społecznych. W ten sposób „obszary” przekształcają się w ważne dla zbiorowości „miejsca”, przestrzenie publiczne, czy też - używając określenia S. Zukin [1995, s. 260-261] - „okna do duszy miasta”. Można powiedzieć, że przestrzenie publiczne to zbiorowo tworzone, wielowątkowe przekazy, skierowane do aktualnych i przyszłych mieszkańców, ale także do wielu różnych użytkowników. Wspomniana wielowątkowość zakodowanych w przestrzeniach publicznych „opowieści” wynika z współistnienia licznych czasów społecznych, odmiennych idei i tradycji przechowywanych i przekazywanych przez środowiska tworzące heterogeniczną zbiorowość miejską. Czasami jednak wyraźnie jest dostrzegana dominacja pewnych wartości w kształtowaniu przestrzeni społecznych. Charakterystyczny przykład przedstawia R. Swentzell, historyczka, architektka, artystka, opisując włączenie do tradycyjnego krajobrazu Santa Clara Pueblo (Nowy Meksyk, USA) nowego elementu, jakim była szkoła dla rdzennej ludności tych terenów. Dla Indian całe ich środowisko mieszkalne było jednocześnie przestrzenią pamięci o przeszłości, o przodkach często grzebanych pod podłogą chat i jednocześnie przestrzenią świata natury, odzwierciedlającą koncepcję uniwersalnego porządku i miejsca człowieka jako jego elementu. "Rządowa” szkoła nie tylko tworzyła świat całkowicie osobny materialnie (spadzisty dach, ogrodzenie zamykające wydzieloną przestrzeń, zupełnie inny rozkład pomieszczeń, wydzielone miejsce do zabawy i sportu, urządzone w całkowicie obcy dla Indian sposób itd.), ale także symbolicznie. Przestrzeń szkoły podporządkowana była wizji budowy społeczeństwa amerykańskiego, zjednoczonego poprzez odwoływanie się do konstytucji, do wartości dominujących narzuconych przez tzw. WASPs ${ }^{1}$ [Swentzell 1997, s. 56-65]. Inna obecna w wielu krajach kwestia to relatywna nieobecność kobiet i ich historii w przestrzeniach pamięci, co wiąże się z tradycyjnymi rolami społecznymi, które od wieków były im przypisane. Przez wieki miasta tworzyli mężczyźni dla mężczyzn, w wielu kulturach

${ }^{1}$ Skrót ten oznacza White-Anglo-Saxon-Protestant i odnosi się zazwyczaj do grup dobrze sytuowanych Amerykanów odgrywających kluczową rolę w kształtowaniu zasadniczych zrębów tradycji i kultury Stanów Zjednoczonych Ameryki Północnej. 
domeną kobiet była przestrzeń domu i najbliższego otoczenia. Dopiero niedawno zaczęto zastanawiać się nad problemami funkcjonowania miast z punktu widzenia kobiet i możliwościami uczynienia miast bardziej przyjaznymi dla kobiet. Dotyczy to zwłaszcza krajów, w których kobiety nadal mają niską pozycję społeczno-ekonomiczną. Kobiety także inaczej korzystają z przestrzeni miejskiej, która jednak nie jest przystosowana do ich potrzeb. Zarówno w krajach rozwijających się, jak i w krajach rozwiniętych, np. w Austrii (w Wiedniu) realizowane są programy związane z lepszym dostosowaniem organizacji przestrzeni miejskiej do potrzeb kobiet (http://www.citylab.com/commute/2013/09/how-design-city-women/6739/, data dostępu: 21.03.2016). Jak wskazuje P. Tobiasz-Lis [2008], kobiety w inny sposób postrzegają przestrzeń, mają inne skojarzenia wartościujące. Jednak wyraźne współcześnie uwrażliwienie na odmienne użytkowanie przestrzeni przez przedstawicieli obu płci nie wpływa, w dużym stopniu, na obecność „kobiecej historii" w przestrzeni miasta, na charakter przestrzeni pamięci ${ }^{2}$. Powoli się to zmienia, w Stanach Zjednoczonych (podobnie jak uznano wpływ Afroamerykanów za ważny element budowania przestrzeni pamięci w mieście [Hayden 1997, s. 169-171], zaczęto odkrywać historyczne doświadczenia kobiet, mniej spektakularne, pozornie mniej „,bohaterskie” (zwłaszcza w najbardziej upowszechnionym sposobie definiowania bohaterstwa) tworzące historię publiczną [Hayden 1997, s. 139-167].

Analizując przestrzenie społeczne miasta, zwłaszcza przestrzenie symboliki, można dostrzec ich nieciągłość, porowatość wynikające z samego charakteru miejskich praktyk, niemożności ostatecznego przesądzania o ich kształcie [Stavrides 2006, s. 2-3]. Te atrybuty szczególnie widoczne są w przestrzeniach pamięci, które tworzą nie zawsze spójną strukturę prowokującą do dyskusji i sporów o przeszłość (i teraźniejszość).

Pamięć jest bowiem, jak podkreśla P. Nora [2009, s. 7], wielkim magazynem, z którego można wybrać dowolne elementy. Zatem chodzi o to, co i jak pamiętamy, co chcemy zachować, a co odrzucić, o czym zapomnieć. Jak wskazuje M. Halbwas obraz w naszej pamięci wcale nie oddaje obiektywnego przebiegu wydarzeń, ani tym bardziej uczuć i emocji towarzyszących tym wydarzeniom. Zawsze jest to jakaś interpretacja i kolejne pokolenia wytwarzają swoje wersje przeszłości [Halbwachs 2008, s. 137].

${ }^{2}$ Marcin Napiórkowski w książce pt. Powstanie umarłych. Historia pamięci 1944-2014opublikowanej w 2016 r. przez wydawnictwo Krytyki Politycznej poświęca sporo miejsca pamięci o kobietach, uczestniczkach Powstania Warszawskiego, które chociaż były sanitariuszkami czy „matkami, siostrami, żonami powstańców”, to także walczyły z bronią w ręku. Brak jednak nie tylko upowszechnionej wiedzy, ale także przestrzeni pamięci w Warszawie, które uwzględniałyby ten fakt. 
Spory o pamięć, a czasem nawet o „prawo do pamięci” zaznaczają się także w przestrzeniach publicznych, w których odbywa się swoista gra o symbole, podejmowane są działania związane z konstruowaniem i organizowaniem pewnych miejsc zgodnie ze „swoją” pamięcią i, jednocześnie, wymazywaniem elementów odwołujących się do pamięci „cudzych”, zwłaszcza „niechcianych”. Trudne, wstydliwe wydarzenia z przeszłości są skwapliwie usuwane ze świadomości, a ich ślady z otoczenia materialnego. Często powstałe w ten sposób luki uzupełniane są przez idee, wyobrażenia czy symbole przyjemniejsze, nie pozostawiające miejsca na wątpliwości [Pajaczkowska 2005, s. 23]. Powstające w ten sposób przestrzenie pamięci naznaczone są często uproszczeniem czy fałszem, stają się obiektem kontestacji, a nawet ,zemsty”. Ich tworzenie i podtrzymywanie sprzyja fragmentacji miasta. Efektem tego procesu w sferze społecznej może być zanikanie poczucia wspólnoty i poczucia przynależności do jednej, wyraźnie zdefiniowanej, całości. Społeczna i przestrzenna fragmentaryzacja miasta jest jednocześnie procesem fragmentaryzacji kulturowej. Rozpad kultury danego miasta na osobne i nieprzystające do siebie części jest procesem w pewnym sensie nieuniknionym, jest rezultatem wzrastającej różnorodności, nierównej „siły społecznej” poszczególnych grup i środowisk. Elementami obrazu konkretnego miasta są zazwyczaj ważne obszary kulturowe, czy np. istotne wartości symboliczne, czy właśnie przestrzeni pamięci, które przynależą tylko do pewnych grup. W ten sposób powstaje kulturowa i przestrzenna porowatość miasta utrudniająca tworzenie całości, z którą wszyscy lub większość mieszkańców i użytkowników miasta mogłoby się identyfikować.

W analizie tych zjawisk pomocne są pewne metafory odzwierciedlające sposób, w jaki różne strony (różne grupy czy kręgi) zaznaczają swoją obecność i jakie są efekty tych działań. Często używana jest metafora „palimpsestu” odwołująca się do wielowarstwowości współczesnego miasta, w którym kolejne generacje wykorzystują istniejące miejsca do nadawania im nowych znaczeń lub nowych form materialnych (wymazując uprzednio dawne). Warstwy wcześniejsze jednak, nawet jeśli przestały istnieć, zazwyczaj mogą być odzyskane w procesach analizy historycznej [Madurowicz 2009, s. 55]. Można także użyć metafory „śladu” drobnego zazwyczaj elementu zaobserwowanego w przestrzeni, ale także śladu po czymś, co dawniej istniało, po materialnym obiekcie, zwyczaju, rytuale. Wreszcie można wskazać, że w miejskim krajobrazie pamięci toczy się „walka”, symboliczna lub nawet dosłowna prowadzona przez różne podmioty, zarówno przedstawicieli władzy, jak i mieszkańców, rozmaite organizacje i inne siły dążące do władania przestrzenią [Rybicka 2011, s. 203]. Problemem jest przypominanie, wcześniej wykluczonych (z różnych powodów), fragmentów dziedzictwa i ponowne włączanie ich do miejskich przestrzeni symbolicznych. Te nowe elementy niekoniecznie dają się bezkonfliktowo „dodać”, często samą swoją 
obecnością eksponują wcześniejsze milczenie i przyczyniają się do podnoszenia kwestii nie zawsze wygodnych dla różnych aktorów życia społecznego. Ponadto mieszkańcy i użytkownicy miasta są w stanie przywyknąć do pewnej „trwałości”, a nawet nienaruszalności" dziedzictwa, na podstawie którego tworzone są poczucie stabilności, przynależności, a nawet dumy. Zachwianie tej stabilności może, jak wskazuje S. Macdonald [2008, s. 93-94], wprowadzić do świadomości zbiorowej elementy niepewności, kontestowania dotychczas akceptowanych jako „fakty” elementów historii. Takie działanie może być podejmowane świadomie z różnych motywów, w tym także w celu manipulowania zbiorowymi emocjami.

W warunkach miasta heterogenicznego etnicznie, religijnie należy także brać pod uwagę, w jakim stopniu funkcjonuje ono jako swoisty teren ,pogranicza kultur" w sytuacji, gdy mieszkańcy i użytkownicy znajdują się na co dzień wobec konieczności konfrontowania swoich wartości, przekonań i wierzeń z tymi, które cenią i akceptują inni, co więcej są to „,inni”, z którymi trzeba negocjować, współpracować, dzielić tę samą przestrzeń, wspólnie korzystać z tych samych usług i instytucji.

Wytwarzane zbiorowo i indywidualnie miejskie przestrzenie pamięci zawsze są przynajmniej w pewnym stopniu „w trakcie przemian”, płynne, są efektem interpretacji i reinterpretacji wydarzeń należących zarówno do wielkiej tradycji narodowej, tradycji lokalnych, czy wreszcie przeżyć i interesów rozmaitych grup i jednostek, a także instytucji. Niektóre z nich mogą mieć charakter fasadowy, w tym sensie, że są tworzone i eksponowane (a nawet „lansowane”) na użytek konkretnej ideologii, w związku z określoną (na przykład korzystną dla grupy dominującej) wersją historii. Mogą być także oparte na fałszu (świadomym lub przypadkowym), jeśli zmienia się sens wydarzeń z przeszłości, wybiela, upiększa, pomija niektóre szczegóły.

Przestrzenie te pełnią ważne role społeczne, są one istotne dla budowania wspólnoty pamięci ${ }^{3}$, dumy mieszkańców danego obszaru, wspierają poczucie ciągłości i związku z danym miejscem, pełnią zatem funkcje integracyjne. Jednocześnie jednak mogą wspierać podziały społeczne, dostarczając uzasadnień do wykluczania czy marginalizowania określonych grup. Przestrzenie pamięci zatem mogą być i bywają narzędziem dominacji. Są one także podstawą do budowania miejskich narracji tworzonych nie tylko przez mieszkańców i użytkowników przestrzeni, ale i poprzez celowe działania różnych instytucji zarówno lokalnych, jak i regionalnych czy krajowych. Formułowanie tych komunikatów (przekazów) jest

3 Wspólnota pamięci może wynikać z urodzenia się w danym środowisku społecznym lub z dokonanego wyboru co do wizji przeszłości. Oznacza pewną zbiorowość, która połączona jest określonym doświadczeniem biograficznym. Do tej wspólnoty należą także osoby, które, nie mając tego osobistego doświadczenia, akceptują je jako swoje (np. poprzez przekazy rodzinne) [Skoczylas 2014, s. 12]. 
procesem skomplikowanym, zwłaszcza w warunkach wielokulturowości miasta oraz w warunkach zderzania się tradycji ,chcianych” i „,niechcianych” i zmieniających się uwarunkowań.

Opowieści o miejscu, wyrażone w sposobach zorganizowania przestrzeni, wyposażenia jej w treści symboliczne, ale też w sposobach jej interpretowania i oceniania, odgrywają istotną rolę w budowaniu tożsamości zarówno w wymiarze indywidualnym, jak i zbiorowym, w tworzeniu (wzmacnianiu) prestiżu miejsca. Inna ich ważna funkcja może być określona jako „katalityczna” w tym sensie, że wywołuje zarówno pewne emocje, jak i pewne działania jednostkowe lub zbiorowe.

Przestrzenie pamięci dostarczają też materialnych ram do rozwijania interakcji społecznych, zwłaszcza prowadzenia dialogu pomiędzy różnymi pokoleniami, różnymi grupami społecznymi. Przestrzenie pamięci organizują również nasze doświadczanie miasta. Ta relacja między człowiekiem a środowiskiem mieszkalnym obejmuje zarówno doświadczanie jego materialnego kształtu i funkcjonalności, estetyki, jak i poczucia bezpieczeństwa swojskości, zakorzenienia, jak i rozumienia jego sensu, czyli „odczytywania znaczeń wpisanych w to miejsce” [Żmudzińska-Nowak 2010, s. 100].

\section{Miasta o trudnej historii i ich przestrzenie pamięci}

Można powiedzieć, że każde miasto ma w jakimś sensie trudną historię, choć oczywiście niektóre bardziej (znacznie bardziej) niż inne. To mogą być np. miasta budowane przez zwycięskich najeźdźców, miasta kolonialne, miasta pogranicza ${ }^{4}$, w których ścierały się i walczyły ze sobą różne kultury, miasta które w toku dziejów należały do różnych organizmów państwowych, znajdowały się w obszarze odmiennych kręgów kulturowych, czy miasta których funkcjonowanie podporządkowywano określonym ideologiom.

Szczególnym przypadkiem miast o trudnej historii są „miasta podzielone”, występujące w różnych formach. Niektóre z nich zostały dosłownie „podzielone” granicami państw nieraz brutalnie przecinającymi parki, ulice, społeczności lokalne wspólnoty kulturowe. Inne są podzielone w tym znaczeniu, że w ich obrębie istnieją obok siebie rozmaite skupienia społeczne o odrębnych wartościach, wytwarzające odrębne światy, zarówno w sensie materialnym (przestrzeń), jak i niematerialnym (praktyki życia miejskiego). Te podziały mogą opierać się na

\footnotetext{
${ }^{4}$ Miasta pogranicza to złożone zagadnienie, którego rozważenie wykracza poza ramy niniejszego artykułu. Przywołane jest tutaj ze względu na fakt, że jest to niewątpliwie przykład miasta o trudnej historii, podobnie jak inne, których dzieje spowodowały nagromadzenie rozmaitych konfliktów, zarówno społeczno-kulturowych, politycznych jak i związanych z przestrzeniami, zwłaszcza symbolicznymi.
} 
różnicach religijnych, etnicznych czy rasowych; mogą mieć źródło w różnicach ekonomiczno-społecznych i statusowych (warto dodać, że te podziały mogą się na siebie nakładać). Podziały w miastach wynikają także z przebiegu ich historii, zmian w statusie różnych grup mieszkańców, znikanie jednych (często w bardzo tragicznych okolicznościach), pojawianie się innych.

Bardzo wyraźny, wręcz skrajny, przykład rozpadu miasta na odseparowane fragmenty, właściwie nieprzenikalne nawzajem, widoczne są w wielkich miastach Republiki Południowej Afryki, nawet kilkanaście lat po zniesieniu apartheidu nie został jeszcze przezwyciężony. Można wymienić pięć odrębnych „miast” będących rezultatem polityki apartheidu, w tym także przymusowych wysiedleń, ustanawiania granic etnicznych, mieszczących się w ramach drugiego co do wielkości ośrodka miejskiego RPA - Durbanu. Są to: miasto śmierci (the city of death), miasto przetrwania (the city of survival), miasto nadziei (the city of hope), miasto możliwości (the city of entitlement), wreszcie miasto obfitości (the city of superfluity). Mieszkańcy każdego z tych „miast” postrzegają mieszkańców pozostałych jako zagrożenie [Sutcliffe 1996, s. 67-72]. Łatwo wyobrazić sobie, jak odmienne i odseparowane od siebie są przestrzenie pamięci w tego typu miastach, funkcjonujących w warunkach bardzo wysokiego poziomu fragmentacji. Historia „kolorowych” została oficjalnie zauważona dopiero po zniesieniu polityki apartheidu i włączona do sytemu szkolnictwa ${ }^{5}$, a także pośrednio - do zasobu pamięci społeczeństwa jako całości [Mouton, Louw i Strydom 2012, s. 1211-1212].

Wspominając o możliwościach minimalizowania konfliktów w podzielonych miastach, Annika Björkdahl wskazuje na konieczność rozwijania strategii „budowania pokoju” m.in. poprzez „odetnicznianie” przestrzeni miejskiej i budowanie narracji miejskich bez podkreślania historycznych sporów i konfliktów ${ }^{6}$. W miastach, takich jak: Nikozja, Belfast czy Mostar, proces tworzenia miejsc pamięci może być wkładem w rozwiązywanie problemów lub, przeciwnie, oznaczać antagonizowanie i wzmacnianie istniejących konfliktów.

Trudna historia miasta wiąże się często ze zmianą przynależności państwowej, narodowej, inwazją i zajęciem danego obszaru, zmianami demograficzno-ludnościowymi czy ze zmianą reżimu politycznego, oficjalnej ideologii. W zmienionej sytuacji, władza, zwłaszcza nowa, dąży do jak najszybszego zaznaczenia swojej obecności, podporządkowania istniejących instytucji miejskich, uzasadnienia swoich decyzji i wprowadzanych modyfikacji, ale także do zawłaszczenia przestrzeni miejskiej. Dzieje rozmaitych wojen, od starożytnych do najbardziej

${ }^{5}$ South African Schools Act No. 84 OF 1996 w preambule zawierał m.in. obowiązek ochrony i rozwoju różnorodności kulturowej i językowej https://www.gdeadmissions.gov.za/Content/Files/ SchoolsAct.pdf (data dostępu: 27.07.2016).

${ }^{6}$ Dosłownie postulat ten formułowany jest w następujący sposób: Urban peacebuilding is thus about transforming ethnoscapes into peacescape [Björkdahl 2014, s. 2]. 
współczesnych pokazują, że zdobycie największych miast, a zwłaszcza stolicy, jest kluczem do opanowania kraju, wszystkich obszarów życia społecznego, gospodarczego, kultury, pozwala zawładnąć najważniejszymi przestrzeniami symboliki. W każdym niemal przypadku chodzi nie tylko o zawłaszczanie ważnych przestrzeni, ale również o tworzenie nowych, wśród których szczególną rolę odgrywają na nowo zdefiniowane przestrzenie pamięci odzwierciedlające aktualną wersję przeszłości. Elementy dawnych narracji są często sprzeczne ze sobą, opowiadają o przeszłości z odmiennych perspektyw. Dokonywanie arbitralnego wyboru pewnych wydarzeń, symboli czy wspomnień i odrzucanie innych prowadzi do kształtowania fałszywego obrazu, który nie jest w stanie pełnić ważnych, oczekiwanych funkcji społecznych. Należy wskazać, że tworzenie spójnej opowieści o mieście jest bardzo istotnym elementem polityki miejskiej nakierowanej na budowanie więzi społecznych i stymulowanie integracji.

\section{Miasta o trudnej historii w Polsce}

Miasta w Polsce ze względu na specyfikę dziejów tworzą wysoce złożone, heterogeniczne środowiska społeczno-przestrzenne i kulturowe. Ograniczając rozważania tylko do ostatnich dwóch wieków, można dostrzec, jakie przemiany zachodziły w przestrzeni, zwłaszcza miejskiej, w sposobie zorganizowania życia społecznego, w gospodarce, kulturze. Obecny przestrzenny, społeczny, kulturowy kształt miast jest efektem wydarzeń i procesów okresu zaborów, obu wojen światowych i związanych z nimi zmianami granic, odzyskania niepodległości w 1918 r., głębokich przekształceń we wszystkich dziedzinach życia po 1945 r. Powstawały nowe sposoby zagospodarowania i organizacji przestrzeni najpierw zawłaszczanych przez zaborców, okupujące wojska, a następnie odzyskiwanych i na różne sposoby repolonizowanych.

Po 1945 r. w nowej rzeczywistości politycznej miasta miały odegrać szczególną rolę w kształtowaniu socjalistycznego ładu. Jednym z ważnych obszarów działań było wytwarzanie na nowo społecznych miejskich przestrzeni, proces zdominowany przez decyzje polityczne, związane m.in. z realizowaniem celów ideologicznych, przede wszystkim budowaniu (konstruowaniu) nowego typu społeczeństwa. Miało być egalitarne, masowe, o specyficznym rodzaju struktury społecznej, opartym na dominacji wielkoprzemysłowej klasy robotniczej, podporządkowane władzy centralnej. Przemysł uznano za najważniejszy czynnik miastotwórczy zatem fabryki lokowano w miastach, co narzucało im rolę w strukturze kraju, określało miejskie funkcje i hierarchię ważności, kształtowało warunki bytowe i podstawy oraz kierunki rozwoju [Prawelska-Skrzypek 1990, s. 20]. Układano też na nowo historię budowanych i rozbudowywanych miast, jak w przypadku 
Nowych Tychów. Potocznie uważano, że historia tego miejsca zaczęła się od 1950 r. wraz z decyzją Prezydium Rady Ministrów o budowie nowego „socjalistycznego miasta". W rzeczywistości Nowe Tychy powstały nie na tzw. surowym korzeniu, ale na obszarze uzyskanym dzięki destrukcji istniejących wcześniej wartości przestrzennych i kulturowych. Zniszczone zostały przestrzenie zieleni, zmieniono funkcje terenów rolniczych, degradacji uległ układ przestrzennych powiązań między miasteczkiem i okolicznymi wsiami. Zdewastowano także ważne przestrzenie pamięci - jeden z bardziej interesujących zespołów małej architektury sakralnej na Górnym Śląsku [Lipok-Bierwiaczonek 1993, s. 37-39].

Przestrzeń w mieście socjalistycznym była „zawłaszczana” przez organizacje przemysłowe, przekształcana głównie w przestrzenie produkcji. Charakterystyczne, że gospodarowanie przestrzenią odbywało się w sposób niebywale rozrzutny, co związane było nie tylko z przyjętym systemem wartości, ale także ze sztucznie utrzymywanymi, niezwykle niskimi, kosztami uzyskiwania terenu i dostępu do wody [Jałowiecki 1988, s. 205]. Przestrzenie konsumpcji, symboliki, władzy, wymiany były przejmowane przez elity rządzące, które dążyły do utrwalenia w kompozycji urbanistycznej, w ikonografii miejskiej, w kształtach domów itp. nowych zasad ustrojowych, podkreślania dominującej ideologii i nowego tzw. socjalistycznego systemu wartości.

Szczególnie ważne z punktu widzenia interesów nowego systemu było zawłaszczanie przestrzeni symbolicznej. Władze państwowe uzurpowały sobie prawo do decydowania o tym, co jest ważne dla społeczności miast i o sposobie wyrażania owej ,ważności” poprzez organizację przestrzeni, dekoracje, ikonografię miejską, elementy małej architektury itd. Powstawały w ten sposób oficjalne miejsca pamięci, obszary „ważne”, „święte”, które miały pełnić funkcje integrujące w społeczności miejskiej, niejako przedstawiać jej zbiorową pamięć obejmującą jednak tylko wybrane elementy. Obok istniejących (zmienianych zgodnie z nowymi potrzebami) powstawały nowe przestrzenie symboliczne, nowe dekoracje do wielkich spektakli związanych z propagandą nowego ustroju jego osiągnięć, jego wielkości i trwałości. Typowe dla socjalistycznych reżimów były wielkie mauzolea budowane dla „ukochanych przywódców”, wielkie place centralne, ,pałace” kultury i inne „miejsca najbardziej aktywnego życia społecznego i kulturalnego [...] przychodzą tu miliony ludzi, aby bezpośrednio zetknąć się z przeszłością i współczesną historią, aby spędzić wolny czas na obcowaniu z najwyższymi wartościami kulturowymi narodu, aby wziąć udział w ważnych wydarzeniach społeczno-politycznych" [Goldzamt i Szwidkowski 1987, s. 372].

Po 1989 r. pojawiły się typowe dla miast postsocjalistycznych problemy z dostosowywaniem przestrzeni miejskiej do przemian potrzeb i wartości, np. wzrost poszanowania dla własności prywatnej i wyraźne jej oddzielanie od własności społecznej czy państwowej, poszanowanie prywatności, indywidualizm, 
wpływ wzorów kultury zachodniej, dążenie do wzbogacenia się i demonstrowania własnej zamożności itp. Rozpoczęło się przywracanie dawnych nazw, dawnych funkcji miejscom czy budynkom. Także nowe elementy przestrzeni miasta często budowano i organizowano na podstawie dawnych (przechowanych) wzorów czy zasad. Odzyskiwaniu przestrzeni miasta dla działań spontanicznych jego mieszkańców, dla ekspresji istniejących, zróżnicowanych potrzeb różnych środowisk i grup, towarzyszą jednak zjawiska niekoniecznie powszechnie akceptowane. Takie kontrowersyjne wydarzenia, to $\mathrm{np}$. bardzo komercyjne wydarzenia towarzyszące świętom Bożego Narodzenia czy Wielkiej Nocy, a także uroczystościom patriotycznym, w odniesieniu do których ujawniają się coraz częściej różnice w sposobach postrzegania przeszłości (dalszej i bliższej), wydarzenia dokonujące się ponad dwie dekady temu podlegają obecnie zróżnicowanym interpretacjom. Toczące się spory historyczne (i jeszcze bardziej zacięte debaty publiczne i medialne) wokół drugiej wojny światowej, Powstania Warszawskiego, stosunków z najbliższymi sąsiadami, relacji polsko-żydowskich i innych powodują konflikty wokół miejsc pamięci i generalnie przestrzeni symbolicznych (cmentarzy, pomników, tablic pamiątkowych itp.).

Im bardziej złożona historia miasta w wyniku zmiany granic, tym częściej pojawiają się konflikty w przestrzeni symbolicznej i spory o przeszłość i pamięć o tej przeszłości. Przykładem może być historia pomnika hrabiego F. Wilhelma von Redena, twórcy górnośląskiego przemysłu i założyciela wielu śląskich miast. Jego ostateczne odsłonięcie w Chorzowie poprzedzone było wielką kampanią protestów, a na cokole pomnika działacze Konfederacji Polski Niepodległej Obóz Patriotyczny rozpięli transparent z napisem: Pomnik Prusaka - policzek dla Polaka ${ }^{7}$.

Jeszcze bardziej skomplikowana jest sprawa dziedzictwa żydowskiego w Polsce. $Z$ jednej strony pojawiają się postawy odrzucenia i niechęci, jak np. w Poznaniu, gdzie pod powierzchnią podwórza jednej z kamienic znajduje się jedyny ocalały fragment starego żydowskiego cmentarza z grobem słynnego na całą Europę rabina Akiby Egera. Mieszkańcy kamienicy nie życzą sobie jednak przypominania tego dziedzictwa [Kolbuszowska 2005]. Dramatyczne losy cmentarzy żydowskich w Polsce (ponad 400 zniknęło z powierzchni ziemi i często także z pamięci ludzkiej) przedstawia album Ł. Bagsika Macewy codziennego $u \dot{z} y t k u$ (wyd. w 2013 r.). Autor dokumentuje barbarzyńskie rozprawianie się z przestrzeniami pamięci swoich dawnych sąsiadów - już po II wojnie światowej Polacy używali kamieni nagrobnych z żydowskich cmentarzy jako budulca, materiału na kamienie szlifierskie, koryta itp.

7 Informacje o tym wydarzeniu zamieściła „Gazeta Wyborcza” w wydaniu z dnia 18-19 września $2004 \mathrm{r}$. 
Jak wskazuje przykład dawnej żydowskiej dzielnicy Krakowa - Kazimierza, właściwie wykorzystane dziedzictwo żydowskie może stać się zasobem rozwojowym. Choć jednocześnie warto pamiętać, że po wojnie, w 1945 r. z 11 tysięcy Żydów pozostało na Kazimierzu zaledwie 500 osób i mimo że w następnych kilku latach niektórzy z ocalałych wrócili, ich dawny świat nie odrodził się. Można powiedzieć, że żydowska tradycja Kazimierza, a także ocalałe resztki materialnego dziedzictwa kulturowego nie miały w tym okresie obrońców, a tym bardziej „dziedziców”, dla których byłaby to ważna podstawa tożsamości. Współcześnie dziedzictwo żydowskie na Kazimierzu jest eksploatowane jako atrakcja turystyczna.

Bardziej współczesnym źródłem wieloetniczności miast polskich są procesy przemian związanych ze skutkami II wojny światowej, masowych migracji sprzyjających tworzeniu się heterogenicznych zbiorowości, szczególnie na obszarach tzw. Ziem Odzyskanych, ale także w innych miastach przyciągających zazwyczaj możliwościami lepszej pracy, edukacji, kariery, wyższego poziomu życia. Tak kształtowała się wielokulturowość miast Górnego Śląska, Wrocławia, Gdańska, Białegostoku i innych miejsc, gdzie na „stare” podziały etniczne nakładały się nowe ${ }^{8}$.

\section{Gliwice - miasto trudnej historii i wielu narracji}

Jednym z interesujących miast Górnego Śląska są Gliwice, o których we wstępie do przewodnika po Gliwicach pisał ówczesny dyrektor miejskiego muzeum: „dzięki Gliwickim Dniom Dziedzictwa Kulturowego wiemy już dzisiaj, że żyjemy w miejscu niezwykle bogatym w świadectwa przeszłości. Pokazały one jak rozlegle jest materialne i duchowe dziedzictwo Gliwic, jak bogaty wkład w historię Górnego Śląska i Europy Środkowej” [Jodliński 2006, s. 7]. To w tym regionie stapiały się od pokoleń różnorodne wpływy m.in. polskie, czeskie, morawskie niemieckie, ale procesem o szczególnym znaczeniu dla ukształtowania się współczesnej kultury tego obszaru było przyspieszenie industrializacji w XIX w. i napływ niemieckich specjalistów. Zajęli oni wyższe stanowiska w administracji, edukacji, w przemyśle, co spowodowało konfrontację kulturową mieszkańców zasadniczo plebejskiego Górnego Śląska z mieszczańską kulturą niemieckich przybyszów [Wódz 1995, s. 30-31]. Skomplikowana historia tego regionu w wiekach XIX i XX powodowała jego peryferyjność polityczną

\footnotetext{
${ }^{8}$ Integracja na Ziemiach Odzyskanych nie była procesem łatwym. Poczucie obcości i odrzucanie dotyczyło nawet takich codziennych elementów rzeczywistości przestrzennej, jak krzewy i kwiaty w ogródkach przydomowych. Nowi mieszkańcy mieszkań poniemieckich na Górnym Śląsku karczowali „niemieckie” jaśminy, by na to miejsce posadzić bardziej „swoje” rośliny.
} 
i kulturową. Przy istotnym znaczeniu gospodarczym, przez wiele dziesięcioleci był zapóźniony kulturowo, pozbawiony liczącej się wykształconej elity, zwłaszcza w przypadku rodzimej ludności [Szczepański 1998, s. 20]. Po 1945 r. nastąpił kolejny, bardzo ważny okres dla historii regionu, rozpoczęty nową sytuacją geopolityczną. Wizja Górnego Śląska obejmowała, oprócz typowej dla całej Polski koncepcji przekształcenia w ,społeczeństwo socjalistyczne”, specyficznie rozumiany „powrót do macierzy”, czyli całkowitą polonizację i repolonizację przestrzeni, kultury, życia społecznego. Problem był złożony ze względu na już istniejące różnice kulturowe mieszkańców tego obszaru (którzy poddawani byli, często upokarzającej, weryfikacji narodowościowej), napływ przybyszów z innych części Polski, tzw. repatriantów z dawnych ziem utraconych w wyniku II wojny światowej, jak i tzw. reemigrantów, którzy w okresie dwudziestolecia międzywojennego emigrowali najczęściej do górniczych ośrodków Francji i Belgii.

Kolejny dramatyczny okres dla Górnego Śląska to nowe usytuowanie geopolityczne po 1945 r. Jednym z głównych celów władzy stało się urzeczywistnienie postulatu ,polskości” Śląska, mieszkańców, kultury, przestrzeni, a także pamięci, zwłaszcza zbiorowej. Intensywna polonizacja miała zarówno formę negatywną (usuwanie wszelkich elementów kultury niemieckiej), jak i pozytywną (intensywne promowanie wybranych elementów polskiej tradycji, stymulowanie rozwoju polskich organizacji) [Madajczyk 2014, s. 200-201]. Było to w istocie niezwykle trudne zadanie, biorąc pod uwagę fakt, że ,typowy człowiek regionu pogranicza urodził się w Gleiwitz, lecz dorastał w Gliwicach, po II wojnie światowej pozostał w tym mieście lub został z niego przymusowo wysiedlony, czy też dobrowolnie pojechał do Niemiec; dla Niemców pozostawał wtedy zbyt polski, opatrywany etykietką Wasserpolake, dla Polaków zbyt niemiecki, szwabski" [Szczepański 1998, s. 27-28].

Kodowanie elementów pamięci społecznej w przestrzeni miasta dokonuje się poprzez utrwalanie rzeczy (artefaktów) pochodzących z przeszłości, jak i przechowywanie (przypominanie) związanych z nimi znaczeń [Golka 2009, s. 119]. Gdy człowiek (grupa społeczna) opuszcza swoje dotychczasowe miejsce i próbuje zakorzenić się w nowej przestrzeni, pojawiają się problemy zarówno w związku z odmiennością nowego środowiska materialnego, jak i z możliwością przeniesienia znaczeń, symboli czy emocji. Nośnikami pamięci w przestrzeni miejskiej są różne elementy materialne: budynki, budowle, nagrobki, tablice pamiątkowe, pomniki, szyldy, napisy na murach przede wszystkim dzieła architektury, ale także nazwy ulic, placów i innych miejsc. Specjalną kategorię stanowią tzw. implanty pamięci stosowane w sytuacjach, gdy potrzebne jest uzupełnianie brakujących elementów, czy wytworzenie nowej ich wersji, zgodnej a aktualnymi priorytetami [Golka 2009, s. 161]. 
Pełnią one także inne role $\mathrm{w}$ przestrzeni miasta i w polityce miejskiej. Ł. Skoczylas [2014, s. 53] zwraca uwagę na pewne trendy w rozwoju miast współczesnych, które (inaczej niż w czasach dominowania modernizmu) szerzej nawiązują do historii, odwołują się do wartości, które wydają się odległe w czasie, a które znowu wracają jako ważne „kotwice” dla budowania wspólnoty. Stosowanie różnego typu implantów pamięci było bardzo wyraźne w kształtowaniu zarówno przestrzeni materialnej Gliwic (i innych miast na Ziemiach Odzyskanych), jak i tworzeniu sfery symboliki czy rytuałów. Na znaczenie rozmaitych elementów przestrzeni publicznej dla budowania tożsamości miasta i jego mieszkańców zwracają uwagę autorzy projektu badawczego dotyczącego trzech konkretnych miast o trudnej historii - Gdańska, Gliwic i Wrocławia [Bierwiaczonek 2015, s. 61]. Warto także przywołać historie prywatne przybywających do miast Ziem Odzyskanych mieszkańców Kresów Wschodnich. Przywiezione przez nich materialne okruchy dawnego życia obejmowały zarówno obiektywnie ważne i cenne przedmioty, takie jak: dokumenty, biżuteria, obrazy, porcelana, ale również zwykłe, jak: wałek do ciasta, żelazko czy klucz do dawnego mieszkania np. we Lwowie. Wszystkie miały oprócz realnej wartości, bardzo ważną cechę status autentycznego świadka dawnego życia ${ }^{9}$. Mimo wielu ograniczeń i restrykcji niektórzy przybysze z Kresów starali się przywieźć także przedmioty związane z historią utraconej małej ojczyzny, które miały pomóc w oswojeniu tego obcego i wcale nie od razu przyjaznego nowego miejsca do życia. Jak wskazuje Bożena Kubit „z niemałym trudem i poświęceniem, a niekiedy nawet narażeniem życia" przywieziono do Gliwic dwa obrazy niezwykle ważne dla społeczności Kresowian. Był to cudowny obraz Matki Boskiej Kochawińskiej (przywieziony w 1944 r. do Starej wsi koło Brzozowa) pochodzący z sanktuarium z okolic Stryja, który najpierw przez wiele lat był (już w Polsce) ukrywany, ostatecznie w 1974 r. został przewieziony do Gliwic. Drugi bardzo ważny, zwłaszcza dla społeczności ormiańskiej, obraz Matki Boskiej Łysieckiej (z parafii Łysiec koło Stanisławowa) został w 1950 r. przewieziony do Gliwic do kościoła ormiańskiego, a w 1989 r. uroczyście koronowany. Obie parafie, w których znajdują się te obrazy, stały się lokalnymi sanktuariami dla osób pochodzących z Kresów [Kubit 2011, s. 103-105]. Obecnie kościoły te stanowią przestrzenie pamięci dla następnych generacji, zwłaszcza poszukujących swoich korzeni.

9 W 1997 r. w trakcie wyjazdu badawczego do Kurytyby związanego z projektem „Dziedzictwo kulturowe Polonii brazylijskiej” mogłam zaobserwować podobne zjawiska. W jednej z miejscowości na drzewie wisiała bardzo stara drewniana kapliczka z początku XX w. kilkakrotnie opasana metalowymi taśmami, które nie pozwalały na jej całkowite rozpadnięcie. Mieszkańcy zapytani, dlaczego nie przeniosą figurki Chrystusa do nowej kapliczki, odpowiadali, że „ta jest jeszcze z Polski” [Karwińska 1997, s. 27-33]. 
Wśród uwarunkowań skłaniających poszczególne grupy do podkreślania swojej odrębności i dążeń do jej zachowania należy wymienić zderzanie się ze sobą odmiennych stylów życia, tradycji, potrzeb i oczekiwań. Sprzyjało to wytwarzaniu się pewnych charakterystycznych enklaw różniących się zagospodarowaniem przestrzeni, praktykami życia społecznego, a nawet osobliwościami języka. Zderzały się ze sobą także pewne mity propagowane przez instytucje władzy oraz oczekiwania i wyobrażenia zarówno dawnych, jak i nowych mieszkańców miast Śląska.

Charakterystyczne działania władzy podejmowane były w stosunku do istniejącego dziedzictwa materialnego i niematerialnego. Dokonywano, często bardzo arbitralnego, wyboru pasujących do nowej narracji elementów, np.: tradycje robotnicze ważne w kulturze górnośląskiej - tak, głębokie przywiązanie do religii nie. Nie akceptowano też żadnych skojarzeń z niemieckością. Rugowano wszelkie jej elementy z przestrzeni sakralnych, a także z cmentarzy, co antagonizowało już i tak skomplikowane stosunki między różnymi grupami mieszkańców i władzą [Rosenbaum 2010, s. 136-139]. Wspomnienia o niemieckiej kulturze były jednak obecne. Interesującego przykładu dostarcza książka Henryka Wańka nosząca znamienny tytuł Finis Silesiae (wydana we Wrocławiu w 2003 r.). Niszczona i znikająca tradycja niemiecka odcisnęła piętno w przestrzeniach prywatnych i publicznych, była widoczna w meblach, obrazach książkach. [...], „fotografie (autorstwa Karla Franza Klose, przedstawiające niemiecką przeszłość, które były punktem wyjścia do napisana książki - przyp. A.K.) pokazują świat niewątpliwie zaginiony. Co więcej był to świat z urzędową systematycznością skazany po 1945 r. na wyrzucenie z pamięci. Na szczęście urzędowe dekrety nie są w stanie wymusić zapomnienia" [Czy Ślqska nie ma?... 2003].

Wspomniane wcześniej ,implanty pamięci społecznej” uzupełniające tkankę przestrzeni miejskiej Gliwic, to np. pierzeje w stylu renesansowym dodane do budynków zlokalizowanych na Rynku, a także wieża dobudowana do tzw. Zameczku Piastowskiego (dziś siedziba Muzeum Miejskiego), który w istocie był istniejącym od XVI w. tzw. Dworem Centryczów (i żadnej ,piastowskiej” wieży nie posiadał). Pewnym paradoksem jest fakt, że owej „polonizacji” i ,odniemczenia” dokonał prof. Franciszek Maurer, który do Gliwic przyjechał z Kresów.

\section{Uwagi końcowe}

Przez wiele lat o kształcie przestrzeni pamięci w Gliwicach decydowały bieżące interesy polityczne. Miasto najpierw niemieckie, potem polskie (socjalistyczne) oferowało swoim mieszkańcom kolejne wersje pamięci o przeszłości. Stosownie do potrzeb przypominano pewne osoby, miejsca, obiekty, wydarzenia historyczne, zwyczaje. Podobnie jak dziadek Adama Zagajewskiego, który chodził 
z wnukiem ulicami Gliwic, a jednocześnie ulicami Lwowa [Kubit 2011, s. 9], wielu innych mieszkańców miasta instalowało swoje niewidzialne, symboliczne, przestrzenie pamięci z Kresów, z innych miast Polski, czy też z innej przeszłości, celowo pomijanej w oficjalnej okolicznościowej retoryce. Obecnie mieszkańcy Gliwic, instytucje kulturalne, w tym zwłaszcza Muzeum w Gliwicach próbują odtworzyć złożoność i wielowątkowość pamięci miasta. Tam, gdzie jest to możliwe, odtwarza się przestrzenie pamięci chociażby symbolicznie, jak np. szlak Żydów gliwickich pozwalający na umiejscowienie tej ważnej kiedyś dla rozwoju miasta zbiorowości, wśród której znajdowało się wielu przemysłowców, kupców, ludzi nauki [Małusecki 2006, s. 63-78]. Historia miasta zatoczyła w pewnym sensie koło: od wielokulturowego miasta przynależnego przez wieki do Europy, poprzez miasto polskie (,piastowskie”!) i jednocześnie socjalistyczne, nie tylko odrzucające wszelkie ślady niemieckości, ale też zaprzeczające dziedzictwu żydowskiemu czy kresowemu - do współczesnego miasta o wielokulturowej teraźniejszości i przyszłości. Należy jednak wskazać, że owe historyczne przestrzenie pamięci współcześnie znowu są często traktowane instrumentalnie jako elementy marketingu miejskiego i koniunkturalnie dobierane w zależności od bieżących potrzeb.

\section{Literatura}

Baucharowicz M. [2012], Przeklęta i błogosławiona (Pamięć jako fundament europejskiej tożsamości w refleksji Czesława Miłosza), „Przegląd Humanistyczny”, rok LVI, nr 6(435).

Bierwiaczonek K. [2015], Przestrzeń publiczna jako przestrzeń tożsamości miasta. Szansa czy balast dla rozwoju miasta?, „Acta Universitatis Lodziensis, Folia Sociologica”, vol. 54, https://doi.org/10.18778/0208-600x.54.05.

Björkdahl A. [2014], Urban Peacebuilding in Divided Cities, http://www.fragilestates. org/2014/01/06/urban-peacebuilding-in-divided-cities/ (data dostępu: 14.07.2016).

Czy Ślaska już nie ma? Z Henrykiem Wańkiem, autorem „Finis Silesiae”, rozmawia Aleksandra Klich [2003], ,Tygodnik Powszechny”, nr 24 (2814), 15 czerwca, http://www. tygodnik.com.pl/ksiazki/24/ksiazki01.php (data dostępu: 10.07.2015).

Goldzamt E., Szwidkowski O. [1987], Kultura urbanistyczna krajów socjalistycznych, Arkady, Strojizdat, Warszawa, Moskwa.

Golka M. [2009], Pamięć społeczna i jej implanty, Wydawnictwo Naukowe Scholar, Warszawa.

Halbwachs M. [2008], Społeczne ramy pamięci, Wydawnictwo Naukowe PWN, Warszawa.

Hayden D. [1997], The Power of Place. Urban Landscapes as Public History, The MIT Press, Cambridge Mass., London.

Jałowiecki B. [1988], Społeczne wytwarzanie przestrzeni, KiW, Warszawa.

Jodliński L. [2006], Wprowadzenie, Gliwice znane i nieznane, Muzeum w Gliwicach, Gliwice. 
Kalandides A. [2007], Fragmented Branding for a Fragmented City: Marketing Berlin, http://www.geography.dur.ac.uk/conferences/Urban_Conference/Programme/ pdf_files/Ares\%20Kalandides.pdf (data dostępu: 1.02.07).

Karwińska A. [1997], Dziedzictwo kulturowe Polonii brazylijskiej. Komentarz socjologiczny [w:] Dziedzictwo architektoniczne polskiej emigracji w Brazylii, red. A. Böhm, Politechnika Krakowska, Kraków.

Kolbuszowska D. [2005], Nie chcq Żydów na podwórku, „Gazeta Wyborcza”, 15 listopada.

Kubit B. [2011], Gliwiccy Kresowianie, Muzeum w Gliwicach, Gliwice.

Lipok-Bierwiaczonek M. [1993], Mit „surowego korzenia” a rzeczywistość kulturowa [w:] Tychy. Problemy miasta i perspektywy ich rozwiqzania, Materiały seminarium, red. M.S. Szczepański, Tychy.

Macdonald S. [2008], Unsettling Memories: Intervention and Controversy over Difficult Public Heritage, https://www.york.ac.uk/media/sociology/Unsettling\%20memories.pdf (data dostępu: 3.08.2015).

Madajczyk P. [2014], Polityka polska wobec ludności Górnego Śląska w latach 1944/451998 [w:] Górny Ślq̨sk i Górnoślqzacy. Wokót problemów regionu i jego mieszkańców $w$ XIX i XX wieku, red. S. Rosenbaum, IPN, Muzeum w Gliwicach, Katowice-Gliwice.

Madurowicz M. [2009], Hermeneutyka miejsca $w$ świetle fenomenologii przestrzeni [w:] Genius loci. Tożsamość miejsca w kontekście historycznym i współczesnym, red. B. Gutowski, Muzeum Pałac w Wilanowie, Warszawa.

Małusecki B. [2006], Rodziny gliwickich przemysłowców pochodzenia żydowskiego - ich udział w życiu i rozwoju miasta [w:] Żydzi gliwiccy, Muzeum w Gliwicach, Gliwice.

Mouton N., Louw G.P., Strydom G.L. [2012], A Historical Analysis of the Post-Apartheid Dispensation Education in South Africa (1994-2011), ,International Business \& Economics Research Journal”, vol. 11, nr 11, https://doi.org/10.19030/iber.v11i11.7369.

Nora P. [2009], Między pamięciq $i$ historiq: Les Linux de Memoire, „Tytuł Roboczy Archiwum", nr 2.

Pajaczkowska C. [2005], Urban Memory/Suburban Oblivion [w:] Urban Memory. History and Amnesia in the Modern City, ed. M. Crinson, Routledge, New York.

Prawelska-Skrzypek G. [1990], Miasta o niesharmonizowanym rozwoju w świadomości mieszkańców, Wydawnictwo Uniwersytetu Jagiellońskiego, Kraków.

Rosenbaum S. [2010], Między dezintegracjq a migracjq. Władze komunistyczne a ludność rodzima w Gliwicach i powiecie gliwickim w latach 1950-1960 [w:] Władza, polityka i społeczeństwo w Gliwicach w latach 1939-1989, red. B. Tracz, IPN, Muzeum w Gliwicach, Katowice-Gliwice.

Rybicka E. [2011], Pamięć i miasto. Palimpsest vs pole walki, „Teksty Drugie”, nr 5, IBL PAN, http://rcin.org.pl/Content/48426/WA248_65486_P-I-2524_rybicka-pamiec.pdf (data dostępu: 27.06.2016).

Sassen S. [2014], The City: Today's Frontier Zone, ,Glocalism: Journal of Culture, Politics and Innovation", nr 3, https://doi.org/10.12893/gjcpi.2014.3.1.

Skoczylas Ł. [2014], Pamięć społeczna miasta - jej liderzy i odbiorcy, Wydawnictwo Scholar, Warszawa.

Stavrides S. [2006], Heterotopias and the Experience of Porous Urban Space, http:// courses.arch.ntua.gr/fsr/125583/loose_space_Stavrides_final.pdf (data dostępu: 26.07.2016).

Sutcliffe M. [1996], The Fragmented City: Durban, South Africa, „International Social Science Journal”, vol. 48, nr 147, https://doi.org/10.1111/j.1468-2451.1996.tb00057.x. 
Swentzell R. [1997], Conflicting Landscape Values: The Santa Clara Pueblo and Day School [w:] Understanding Ordinary Landscapes, eds P. Groth i T.W. Bressi, Yale University Press, New Haven.

Szczepański M.S. [1998], Opel z górniczym pióropuszem: Restrukturyzacja województwa katowickiego i jej społeczne uwarunkowania, Śląsk, Wydawnictwo Naukowe, Katowice.

Tobiasz-Lis P. [2008], Wyobrażenia kobiet i mężczyzn o przestrzeni Łodzi, „Acta Universitatis Lodziensis. Folia Geographica Socio-Oeconomica”, nr 9.

Wódz K. [1995], Revitalization of the Silesian Identity - Chance and Threats [w:] Regional Identity - Regional Consciousness. The Upper Silesian Experience, Wydawnictwo Uniwersytetu Śląskiego, Katowice.

Zukin S. [1995], Culture of Cities, Blackwell Publishers, Oxford.

Żmudzińska-Nowak M. [2010], Miejsce. Tożsamość i zmiana, Wydawnictwo Politechniki Śląskiej, Gliwice.

\section{Spaces of Memory in Cities with a Difficult History - Conflicts in Urban Narrations}

The article discusses the controversies around memory spaces that arise as an effect of historical processes. Different groups of city dwellers and users create their own important spaces and build their vision of the city. By doing so they use urban space and history to most effectively mark their presence in them. Some parts of city may have a difficult history where a wanted and an unwanted heritage coexist. Memory in urban space can be perceived as a tool that helps to define oneself in relation to others. This memory can also be used to create the meaning of one's own actions, choices and evaluation criteria. The author presents different examples of cities with a difficult history to discuss the thesis on the controversial character of memory spaces created by different groups.

Keywords: memory spaces, cities with a difficult history, palimpsest, Gliwice. 